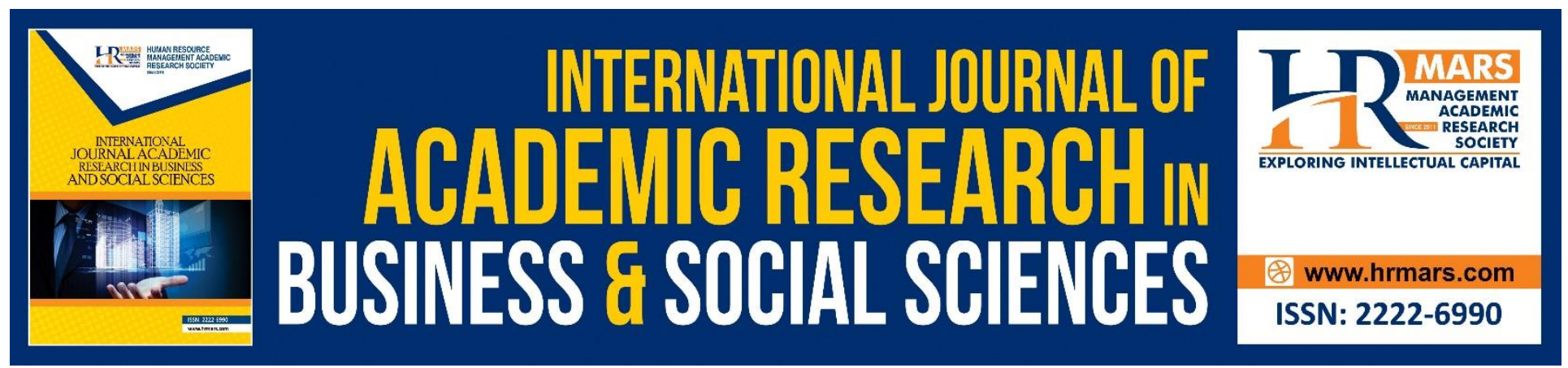

\title{
Effect of Water Technological Factors on Water Accessibility among Residents of Baringo North
}

\section{Shadrack Yator, Josphat Kwasira}

To Link this Article: http://dx.doi.org/10.6007/IJARBSS/v10-i10/7943

DOI:10.6007/IJARBSS/v10-i10/7943

Received: 08 July 2020, Revised: 11 August 2020, Accepted: 15 September 2020

Published Online: 10 October 2020

In-Text Citation: (Yator, and Kwasira, 2020)

To Cite this Article: Yator, S., \& Kwasira, J. (2020). Post Covid-19 Online Business Strategies by Small-scale Entrepreneurs in Malaysia. International Journal of Academic Research in Business and Social Sciences. 10(10), 341-359.

\section{Copyright: (c) 2020 The Author(s)}

Published by Human Resource Management Academic Research Society (www.hrmars.com)

This article is published under the Creative Commons Attribution (CC BY 4.0) license. Anyone may reproduce, distribute, translate and create derivative works of this article (for both commercial and non-commercial purposes), subject to full attribution to the original publication and authors. The full terms of this license may be seen

at: http://creativecommons.org/licences/by/4.0/legalcode

Vol. 10, No. 10, 2020, Pg. 341 - 359

http://hrmars.com/index.php/pages/detail/IJARBSS

JOURNAL HOMEPAGE

Full Terms \& Conditions of access and use can be found at http://hrmars.com/index.php/pages/detail/publication-ethics 


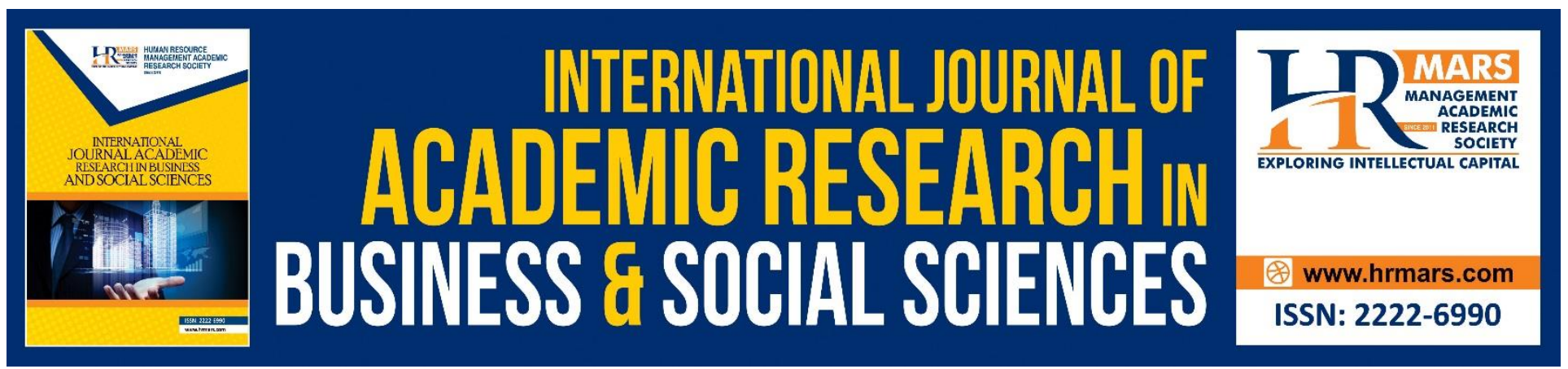

\title{
Effect of Water Technological Factors on Water Accessibility among Residents of Baringo North
}

\author{
${ }^{1}$ Shadrack Yator, ${ }^{2}$ Dr. Josphat Kwasira \\ ${ }^{1}$ Degree of Master of Science in Project Management, ${ }^{2}$ Lecturer Jomo Kenyatta University of \\ Agriculture and Technology
}

\begin{abstract}
In Kenya, one of the millennium development goals is to increase accessibility to clean, safe and affordable water as well as providing proper and efficient sanitation services to all people in the world. Despite the government and non-governmental organizations making good efforts to supply water to citizens, there is still low water supply coverage, especially in rural areas of Baringo North Sub County. The study aimed to examine the effect of water technological factors on water accessibility among residents of Baringo North. The study was informed by technological theory. The study adopted a descriptive research design. The accessible population for this study was 19,734 households' heads, 3 NGOs Water and Sanitation officers, 3 National government agencies, 5 ward administrators, 3 water officers, 12 chiefs and 39 assistant chiefs in Baringo North. The researcher obtained sample size 392 using Yamane formulae. The study used cluster sampling technique, proportionate sampling and simple random sampling technique to select the respondents. The study used semi-structured questionnaires to solicit required data on success factors and water accessibility by residents. A pilot study was conducted in Elgeyo Marakwet County among 39 respondents representing $10 \%$ of the sample size. The study used both descriptive and inferential analysis. The descriptive analysis involved the use of mean, frequencies, standard deviation and percentages. The inferential analysis involved Pearson product-moment correlation and multiple regression analysis. If variables are correlated, then a change in one variable is accompanied by a proportionate change in another variable. The regression model was used to establish a significant difference between water technological factors and water accessibility among the residents. The study findings show that technological factors have a positive and significant influence on water accessibility $(\beta 1=.284, p<0.05)$. The study concluded that technological factors had a direct influence on the implementation of water projects in Baringo North sub-County. Therefore, the study recommends that the county should use technology in water accessibility among residents since the cost of applying technologies to access water is low and will benefit the community.
\end{abstract}

Keywords: Technological, Water, Factors, Supply, Residents. 
INTERNATIONAL JOURNAL OF ACADEMIC RESEARCH IN BUSINESS AND SOCIAL SCIENCES Vol. 10, No. 10, 2020, E-ISSN: 2222-6990 @ 2020 HRMARS

\section{Background of the Study}

Water is an important resource for sustenance of lives and essential resource for social and economic development. Accessibility to an improved source of water refers ito ithe level of the population with the ability to acquire adequate amount of water from an improved source, such as a household connection, public standpipe, borehole and rainwater collection (Connor, 2015). The International drinking Water supply and sanitation decade was declared with the aim of ensuring each individual has access to safe water (Endo, Tsurita, Burnett \& Orencio, 2017). However, one billion people in the world today do not access an improved source of water, and consistent access to safe drinking water not knowing that water being at the center of economic and social development (Garrick \& Hall, 2014).

Shortage of water supply and sanitation occurs due to continuous exploitation of natural resources as well as demographic factors significantly contribute to shape water requirements. Increase in population has been has been major determinant of increases in water demand for domestic uses (Achieno \& Mwangangi, 2018). An increase population especially in urban areas leads to high volume and also high demand of water. Due to increased population, it can make a huge constraint on available local resources (Koskei et al., 2013). Major factor contributing to success of water accessibility include technological factors (Muriuki, 2012).

Technology refers skills and experiences in technical work of the project team. It can either be solar powered system, hand pump operated system or a diesel-powered system and therefore the choices of technology influence accessibility of water (Ko, 2017). Various professionals have used various terms to describe cheap and simple innovations that could be reliable to the locals and performances were better where people were able to make choice in relation to type of system. Among technical factors suggested to contribute to accessibility of services are technology selection, complexity of the technology, the technical capacity of the system to respond to the demand and provide the desired service level, the technical skills required to operate and maintain the system, the availability, accessibility and the cost of spare parts.

In Ukraine, water provision is extremely high. The level of centralized water supply and waste water collection services to its population is also high (Papagiannis, Gazzola, Burak, Pokutsa, 2018). However, the innovation condition of the networks and facilities are ever inadequate in the developed countries. Due to poor technical conditions of the water accessibility systems, it has complicated the quality of urban population life and create a burden on public budgets (Gazzola, 2014). Water supply systems also face a number of technical, socio economic and political issues primarily due to high levels of water supply networks and decrease in value of the equipment, inadequate finance leading to failure pipe water and increased level of energy consumption and waste of drinking water (Burak \& Yurchenko, 2015).

Kenya is known is a water scarce country with an unequal distribution of water whereby some areas have excess and others having less than they require therefore on average it makes the country water scarce (Githua \& Wanyoike, 2015). Due to the unequal distribution, water sources are often far from the village, and women must walk for hours to fetch water on a daily basis. Some families even keep their daughters out of school so that they can help collect water. While walking to get water, particularly when they must walk alone before or after daylight hours, women are vulnerable to rape and other violent attacks. Carrying heavy load over long distances has detrimental health effects, including back and chest pains and developmental deformities. 


\section{Statement of the Problem}

In Kenya, millennium development goals were to increase accessibility to clean, safe and affordable water as well as providing proper and efficient sanitation services to all people in the world. Despite government having a ministry in charge of water affairs ranging from protection of the few water towers, development of infrastructure to water and sanitation services provision, there is still a problem in water accessibility (Koskei, 2019). Owing to the fact that Kenya is a water scarce country and the waters available are not evenly distributed, people who do not have water sources near their places of habitation are forced to walk for kilometers to collect this precious resource (Githua \& Wamyoike, 2015). Baringo North is characterized by inadequate access to water and sanitation. The main water sources in the region are unprotected water pans and dam. The existing high morbidity and mortality from communicable diseases in households in Baringo North areas can partly be attributed to inadequate access to sanitation (Ogada, 2017). They spend many hours to collect the resource, which could have been spent on other activities like subsistence farming or managing small businesses. Despite the government and non-governmental organizations making good efforts to supply water to citizens, it has not been able to cover all areas especially rural areas. Increase in population compared with environment degradation and even deforestation activities have greatly reduced the water accessibility in most part of the subcounty. This has led to an increase in water use and unappropriated water accessibility. Consequently, it has become necessary for communities to organize themselves and launch community water projects to ensure they bring water closer to their homes (WHO, 2014). This study sought to establish the effect of water technological factors on water accessibility among residents in Baringo North, Kenya.

\section{General Objective}

The main aim of the study was to establish the effect of water technological factors on water accessibility among residents of Baringo North.

\section{Research Hypothesis}

$\mathbf{H}_{01}$ : Water Technological factors have no significant effect on water accessibility among residents of Baringo North.

\section{Literature Review}

This chapter looks at the theoretical framework, the conceptual framework and empirical review

\section{Theoretical Framework}

The study was guided by technological theory by Heilbroner.

\section{Technological Theory}

Technological theory was developed by Heilbroner in 1994. The theory has been defined as an approach that identifies technology, or technological advances, as the central causal element in processes of social change. As technology is stabilized, its design tends to dictate users' behaviors, consequently diminishing human agency. This stance however ignores the social and cultural circumstances in which the technology was developed (Drew, 2016). It argue that changes in technology, and specifically productive technology, are the primary influence on human social 
INTERNATIONAL JOURNAL OF ACADEMIC RESEARCH IN BUSINESS AND SOCIAL SCIENCES Vol. 10, No. 10, 2020, E-ISSN: 2222-6990 @ 2020 HRMARS

relations and organizational structure, and that social relations and cultural practices ultimately revolve around the technological and economic base of a given society.

Fast-changing technologies alter human lives. Technological theory sought to show technical developments, technology as a whole, as the key mover in history and social change. It is a theory that shows that consequence of the wide availability of technology, accelerated globalization is inevitable (Mugo \& Nyaegah, 2018). Therefore, technological development and innovation become the principal motor of social, economic or political change. Strict adherents to technological theory do not believe the influence of technology differs based on how much a technology is or can be used (Muhammad, 2018).

The theory assumes that a society's technology determines the development of its social structure and cultural values (Lawson, 2013). Rather than acknowledging that a society or culture interacts with and even shapes the technologies that are used, a technological determinist view holds that the uses made of technology are largely determined by the structure of the technology itself, that is, that its functions follow from its form. Instead of considering technology as part of a larger spectrum of human activity, technological theory sees technology as the basis for all human activity (Cherlet, 2014). Belief in technology is a key governing force in society. 'The idea that technological development determines social change, it changes the way people think and how they interact with others.

Relevant of the technological theory is that it helps in understanding way technology interacts with accessibility of water in the society. Technology is the guiding force in water accessibility, but there is a chance to make decisions regarding the outcomes of water accessibility. A slightly different variant of technology force the society to adjust to the consequences of major inventions, but often does so only after a period of cultural lag. The theory contributes to in understanding of technology selection, its complexity, the technical capacity of the system to respond to the demand and provide the desired service level, the technical skills required to operate and maintain the system, the availability, accessibility and the cost of spare parts (Gracceva \& Zeniewski, 2014).

The criticism of the theory is that modern theorists of technology and society no longer consider technological theory to be a very accurate view of the way in which the society interact with technology, even though theory assumptions and language fairly saturate the writings of many boosters of technology, the business pages of many popular magazines, and much reporting on technology (Wyatt, 2008). Instead, search in science and technology studies, social construction of technology and related fields have emphasized more nuanced views that resist easy causal formulations. They emphasize that the relationship between technology and society cannot be reduced to a simplistic cause-and-effect formula (Pearl \& Mackenzie, 2018). It is, rather, an 'intertwining, whereby technology does not determine but operates, and are operated upon in a complex social field.

\section{Technological Factors and Water Accessibility}

Ivongo and Chege (2019) carried out a study on the effect of information technology on performance of water projects in Makueni County, Kenya. The descriptive research design was selected in this study as it allows the incorporation of both quantitative and qualitative approaches in a study. The results showed that that electronic procurement had a positive and significant effect on the performance of water projects in Makueni County. The study also found that electronic record management had a positive and significant effect on the performance of water projects in Makueni 
INTERNATIONAL JOURNAL OF ACADEMIC RESEARCH IN BUSINESS AND SOCIAL SCIENCES Vol. 10, No. 10, 2020, E-ISSN: 2222-6990 @ 2020 HRMARS

County. Clean, safe and accessible water is an essential component of life in the world and even though there is sufficient fresh water in the planet for use by every person in the world today, due to poor infrastructure, millions of people every year suffer from poor water quality and inadequate water supply. However, the study looks into the effect of information technology on performance of water projects as compared to study objective.

Achieno and Mwangangi (2018) investigated on technology use on sustainability of rural communitybased water projects in Narok County, Kenya. The study employed descriptive survey with a target population of 163 and sample size of 85 respondents selected randomly from 15 community-based water facilities. The study used closed ended questionnaires. Pilot study results were used to test reliability and validity of the instruments found. results revealed that community participation and project management practices have a positive and significant relationship with sustainability among rural community-based water projects while technology use and post implementation support had a low relationship with sustainability of rural community-based water projects. The study however focused on technology leaving aside other factors such as socio economic, legislation and politics.

Tafara (2013) carried out a study to establish the water supply system on sustainability of rural community-based water projects in Mtito Andei, Kibwezi County, Kenya. The study used cross section of people involving those who have been involved in the development of the projects, management, as well as those with expert information or data about the selected community-based water projects. The study also established that sustainability of rural water supply system depends on factors controlled by the project like; training, technology, cost of the project and construction quality. The study established that challenges affecting constant supply of water to the households were due to lack of information management systems, automated systems, appropriate tools and equipment, lack of skills in technology and availability of spare parts. The study however took place in Mtito Andei, Kibwezi County compared to my case study area Baringo North.

Tifow (2013) focused on technology use on sustainability of UNICEF supported community based and managed water supplies in Kisumu and Siaya Counties. A descriptive research design was used. This design allowed for accounting and adequate descriptions of activities, objects and persons. At least $94 \%$ of the respondents agreed that technology influenced the sustainability of UNICEF supported community managed rural water supplies at least to a moderate degree. The findings indicated that where the respondents rated the use of technology highly, the water supply project was equally rated to be more sustainable compared to where use of technology was lowly rated. However, the study focused only on technology leaving aside other factors.

Ondiba and Matsui (2019) studied on study on technology use on sustainable water projects in Shianda Division, Kakamega County, Kenya. Stratified proportionate random sampling techniques were used to select 196 respondents who included community leaders, project leaders, water users/beneficiaries and key informants from the division. The findings further revealed the need for project initiators to involve CMs at all levels of the project cycle as this would build ownership of the project, train and educate $\mathrm{CMs}$ on how to operate and maintain the water facility so that its continuity is not affected by breakdown. The study however studies the factors focused only on technology use leaving other determinants.

\section{Conceptual Framework}

A conceptual framework is a diagram that shows the relationship between the independent and dependent variables under a study (Ngumi, 2013). Figure 1 represents the conceptual framework for 
INTERNATIONAL JOURNAL OF ACADEMIC RESEARCH IN BUSINESS AND SOCIAL SCIENCES Vol. 10, No. 10, 2020, E-ISSN: 2222-6990 @ 2020 HRMARS

this study. The independent variable was technological factors while water accessibility is the dependent variable.

Technological Factors

- Cost

- Innovations

- Tools and Equipment

- Technical Experts

Independent Variables

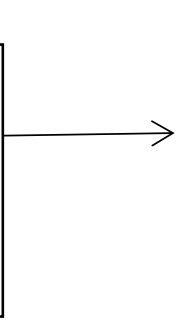

Water Accessibility

- Water Safety

- Readily available

- Reliability

- Environmental Management

\section{Dependent Variable}

Figure 1 Conceptual Framework

\section{Research Methodology Research Design}

Research design is a plan to the research process (Okiro \& Ndungu, 2013). Research design assists in the process of conducting research as it shows how to go about in collecting, measuring and analyzing data (Maxwell, 2012). The descriptive research design was used in this study. It is suitable for description and measurement of phenomena without any biasness.

\section{Target Population}

Population is total collection of the items which researcher wishes to research on. A target population refers to a group of people whose information is desired in a study (Githua \&Wanyoike, 2013). The total population for this study was 19,799 participants in Baringo North. According to Khan (2014) target population is the entire group of individuals or objects to which the researcher was interested in generalizing the conclusions. The target population for this study was household heads, NGOs Water and Sanitation officers, national government agencies, ward administrators, water officers, chiefs and assistant chiefs in Baringo North. According to Flick (2015) accessible population is that part of target population which the study can particularly reach to select a representative sample. The accessible population is subset of target population that can be reached to obtain a sample (Mugenda \& Mugenda 2003). Accessible population for the study was 19,734 household heads, 3 NGOs Water and Sanitation officers, 3 National government agencies, 5 ward administrators, 3 water officers, 12 chiefs and 39 assistant chiefs in Baringo North. Therefore, the total accessible population for the study was 19,799 respondents as shown in Table 1 
INTERNATIONAL JOURNAL OF ACADEMIC RESEARCH IN BUSINESS AND SOCIAL SCIENCES Vol. 10, No. 10, 2020, E-ISSN: 2222-6990 @ 2020 HRMARS

\section{Table 1 Accessible Population}

\begin{tabular}{ll}
\hline Category & Target Population \\
\hline Households & 19,734 \\
NGOs & 3 \\
National Government Agency & 3 \\
Ward Administrators & 5 \\
Water Officers & 3 \\
Chiefs & 12 \\
Assistant Chiefs & 39 \\
Total & $\mathbf{1 9 , 7 9 9}$
\end{tabular}

Source;

\section{Sample Size and Sampling Techniques}

This section will cover how sample size was arrived at and the formula used to calculate. It also presented the sampling technique used to select the respondents who participated in the study.

\section{Sample Size}

The sample size refers to a subset of the population that is taken to be representatives of the entire population (Singh \& Masuku, 2013). The researcher obtained sample size using Yamane formulae (1967).

$$
n=\frac{N}{1+N(e)^{2}}
$$

\section{Equation 3.1}

Where $\mathrm{n}$ is the sample size required

$\mathrm{N}$ is the population size $=19,799$

$\mathrm{e}$ is the level of precision $=0.05$

$n=19,799 /\left(1+19,799 * 0.05^{2}\right)$

$\mathrm{n}=392$

Therefore, the sample size for this study was 392 participants.

Table 2 Sample Size

\begin{tabular}{ll}
\hline Category & Sample size \\
\hline Households heads & 366 \\
NGOs & 1 \\
National Government Agency & 1 \\
Ward Administrators & 2 \\
Water Officers & 1 \\
Chiefs & 5 \\
Assistant Chiefs & 16 \\
Total & 392 \\
\hline
\end{tabular}


INTERNATIONAL JOURNAL OF ACADEMIC RESEARCH IN BUSINESS AND SOCIAL SCIENCES Vol. 10, No. 10, 2020, E-ISSN: 2222-6990 @ 2020 HRMARS

\section{Sampling Techniques}

The study was cluster sampling because the accessible population is mutually homogeneous yet internally heterogeneous groupings are evident. The accessible population was divided into clusters/groups and a simple random sample was used to select participants from each cluster. This sampling technique was used because the researcher would not get information about the population as a whole, but can get information about the clusters. The researcher compiled data from selected clusters and compiles them to get a picture about the sub county. The individual cities would be the clusters in this case. Cluster sampling was important in this study because it allowed selection of only NGOs Water and Sanitation officers, national government agencies, ward administrators, water officers, chiefs and assistant chiefs in Baringo North from the entire population. The method requires fewer resources for the sampling process. Therefore, it is generally cheaper relative as it requires fewer administrative and travel expenses.

\section{Research Instruments}

The study used semi-structured questionnaires to solicit required data on success factors and water accessibility by residents. A questionnaire is a research instrument consisting of series questions for the purpose of collecting information from the respondents (Mugenda \& Mugenda, 2003). It comprises of questions which seek to answer questions relating to objectives of the study. Questionnaires give respondents ample time while giving their responses (Kothari, 2004).

\section{Pilot Testing}

Pilot study refers to rehearsal of research questionnaire on a small number of cases in order to test the procedures and quality of responses. Pilot study is performed in order to test effectiveness of research instrument as it involves duplication and preparation of the main study (Sreeviya \& Sunitha, i2011). A pilot study was conducted in Elgeyo Marakwet County among households, NGOs, national government agency, ward administrators, water officers, chiefs and assistant chiefs. According to Kothari (2014) pilot study involves 10\% of accessible population. Therefore, 39 respondents were involved in pilot study. A pilot study helps in refining the questions by removing some irrelevant items and adding others to genuinely engage with the participants in this study, piloting was done and the instruments were checked to find out if they yield similar results after pre-testing.

\section{Validity of the Research Instruments}

Validity is the extent at which an instrument measures what it is projected for evaluation (Wyatt, 2016). Validity of research instrument is achieved when what is targeted to be investigated is carried out without including extra factors. Content validity was employed in the study to ascertain the appropriateness of research instrument. The validity of this study was attained through experts and seeking advice from the supervisor.

\section{Reliability of Research Instruments}

Reliability is the extent in which there is a consistency in answers using the same instruments more than one time (Cooper \& Schindler, 2014). It is concerned with the estimates of degree to which a measurement is free from random or unstable error. The study used Cronbach's alpha coefficient to estimate the internal consistency reliability by determining how items of the instrument relate to each other and to the entire instrument using data obtained from the pilot test. Thus, it gives great 
INTERNATIONAL JOURNAL OF ACADEMIC RESEARCH IN BUSINESS AND SOCIAL SCIENCES Vol. 10 , No. 10, 2020, E-ISSN: 2222-6990 @ 2020 HRMARS

proportions of reliability since holding different components steady, the more comparative the test substance and states of organization are, the more noteworthy the inner consistency dependability (Kimberlin, i\& Winterstein, 2008). The Cronbach's alpha coefficient ranges from 0.00 - 1.00. Cronbach's alpha of greater than 0.7 is considered acceptable.

\section{Data Processing and Analysis}

Data analysis refers to understand the data that has been collected with an aim to determine consistency of patterns and summarizing the relevant details revealed in investigation (Kiaritha, 2015). The study was both descriptive and inferential analysis. Descriptive analysis involved use of mean, frequencies, standard deviation and percentages. Inferential analysis involved pearson product moment correlation and multiple regression analysis. Regression model was used to establish the significance difference between the water technology factors and water accessibility among the residents.

Therefore, the following multiple regression equation was used.

$Y=\beta_{0}+\beta_{1} X_{1}+\varepsilon$ Equation 1

Where:

$Y$ represents water accessibility

$\boldsymbol{\beta}_{0}$ represents regression constant

$\mathbf{X}_{\mathbf{1}}$ represents water technology factors

$\boldsymbol{\beta}_{1}$, represent the beta coefficients of the independent variable

$\boldsymbol{\varepsilon}$ represents all relevant variables not included in the model

\section{Findings and Discussions}

\section{Response Rate}

Referring to Table 3, out of 392 questionnaires administered to the respondents, 297 were returned, however, 275 were correctly and fully filled thus creating $70.2 \%$ response rate. This response rate was satisfactory to make conclusions for the study as it acted as a representative. According to Mugenda and Mugenda (2003), a response rate of 50\% is adequate for analysis and reporting; a rate of $60 \%$ is good and a response rate of $70 \%$ and over is excellent. Based on the assertion, the response rate was excellent.

Table 3 Response Rate

\begin{tabular}{lll}
\hline Questionnaires & Frequency & Percentages \\
\hline Questionnaire distributed & 392 & 100 \\
Questionnaire returned & 297 & 75.8 \\
Questionnaires correctly and fully completed & 275 & 70.2 \\
Questionnaires not returned & 95 & 24.2 \\
\hline
\end{tabular}


INTERNATIONAL JOURNAL OF ACADEMIC RESEARCH IN BUSINESS AND SOCIAL SCIENCES

Vol. 10, No. 10, 2020, E-ISSN: 2222-6990 @ 2020 HRMARS

\section{Pilot Study Results}

A pilot study was carried out to determine reliability of the questionnaires. The pilot study involved the sample respondents. Reliability analysis was subsequently done using Cronbach"s Alpha, Graziano and Raulin (2013) which measured the internal consistency by establishing if certain item within a scale measures the same construct.

Table 4 Reliability Test Results

\begin{tabular}{llll}
\hline Constructs & Test items & Cronbach alpha & Deduction \\
\hline Technological factors & 4 & .713 & Reliable \\
Water accessibility & 4 & .753 & Reliable \\
\hline
\end{tabular}

The Alpha value threshold at 0.7, Gliem and Gliem (2003) thus forming the study's benchmark. Cronbach alpha was established for every objective which formed a scale. The Table 4 shows that water technological factor had a reliability of $(\alpha=0.713)$ and water accessibility had a reliability of $(\alpha=0.753)$. This illustrates that two the variables were reliable as their reliability values exceeded the prescribed threshold of 0.7. All variables depicted that the value of Cronbach's Alpha was all above value of 0.7 thus the research instrument was reliable (Castillio, 2009).

\section{Demographic Information}

This sub-section investigates on respondent's background information. Mainly it includes age category, gender distribution, education level, occupation and monthly income.

\section{Gender of the Respondents}

The study sought to establish the gender distribution among the respondents. This was sought in view of ensuring fair engagement on male and female respondents. Results are presented in Table 5.

Table 5 Gender of the Respondents

\begin{tabular}{lll}
\hline Gender & Frequency & Percentage \\
\hline Male & 173 & 62.9 \\
Female & 102 & 37.1 \\
Total & $\mathbf{2 7 5}$ & $\mathbf{1 0 0 . 0 0}$
\end{tabular}

Results obtained in Table 5 showed that majority of the respondents as shown by 173(62.9\%) were males whereas 102(37.1\%) were females. This implies that males dominated the study. The majority of male respondents in this study will be very informative since male mostly have more information about water accessibility logistics.

\section{Age Distribution}

Respondents were requested to indicate their age category. This was sought in the understanding that different age sets hold various opinions relating to different issues. Results are shown in Table 6. 
INTERNATIONAL JOURNAL OF ACADEMIC RESEARCH IN BUSINESS AND SOCIAL SCIENCES Vol. 10, No. 10, 2020, E-ISSN: 2222-6990 @ 2020 HRMARS

Table 6 Age Distribution

\begin{tabular}{lll}
\hline Age Distribution & Frequency & Percentage \\
\hline $18-25$ years & 71 & 25.8 \\
$26-35$ years & 85 & 30.9 \\
$36-45$ years & 61 & 22.2 \\
46 years and above & 58 & 21.1 \\
Total & $\mathbf{2 7 5}$ & $\mathbf{1 0 0 . 0 0}$ \\
\hline
\end{tabular}

The findings show that $71(25.8 \%)$ of the respondents were aged between 18 to 25 years, $85(30.9 \%)$ of the respondents were aged between 26 to 35 years, $61(22.2 \%)$ of the respondents were aged 36 45 years and above while 58(21.1\%) of the respondents indicated that they were aged 46 years and above. This shows that various age groups were equitably engaged in this research. The highest age distribution of the study was between 26-35 years of age, this is because this age comprises of the youth population which are more productive and active in the field while the lowest age distribution was age 46 and above which comprises of the elderly hence less active in the area of water accessibility.

\section{Highest Level of Education}

Individual level of education is highly associated with problem solving ability and approach to challenges. In this regard, the study requested the respondent to indicate the highest level of education attained. This was made to determine the respondent's level of ability in answering to research questions. Results are presented in Table 7.

Table 7 Highest Level of Education

\begin{tabular}{lll}
\hline Highest Level of Education & Frequency & Percentage \\
\hline Primary school & 91 & 33.1 \\
Secondary school & 99 & 36.0 \\
Tertiary school & 46 & 16.7 \\
University level & 39 & 14.2 \\
Total & $\mathbf{2 7 5}$ & $\mathbf{1 0 0 . 0 0}$ \\
\hline
\end{tabular}

From the research findings, the study noted that most of the respondents as shown by $99(36.0 \%)$ had secondary level of education, $46(16.7 \%)$ of the respondents held tertiary level certificates, 39(14.2\%) of the respondents had university level of education and 91(33.1\%) had primary level of education. This implies that majority of the respondents were literate and were therefore in a position to give 
INTERNATIONAL JOURNAL OF ACADEMIC RESEARCH IN BUSINESS AND SOCIAL SCIENCES Vol. 10 , No. 10, 2020, E-ISSN: 2222-6990 @ 2020 HRMARS

credible information relating to this study. The high respondent's level of secondary school level was influenced by the fact that most residence never proceed to further studies after secondary schools hence they were important in the study however less proceed to university level as shown by the low respondent's rate in primary level of studies.

\section{Occupation of the Respondents}

Study respondents were requested to indicate their occupation. Results are presented in Table 8.

Table 8 Occupation of Respondents

\begin{tabular}{lll}
\hline Occupation of Respondents & Frequency & Percentage \\
\hline Livestock keeping & 98 & 35.6 \\
Businessman/woman & 25 & 9.1 \\
Crop farmers & 112 & 40.7 \\
Formal employment & 40 & 14.5 \\
Total & $\mathbf{2 7 5}$ & $\mathbf{1 0 0 . 0}$ \\
\hline
\end{tabular}

Results obtained show that, most of the respondents as shown by $112(40.7 \%)$ indicated that they were farmers, followed by $98(35.6 \%)$ who indicated that they were livestock keepers, $25(9.1 \%)$ indicated that they were business people while $40(14.5 \%)$ indicated that they were formal employment. This is important because it shows that majority of the study's respondents at $112(40.7 \%)$ were crop farmers and therefore they were in a position to give credible information relating to this study based on their vast experience. Most of the study respondents were crop farmers because most of the were concerned with water accessibility issues while less Business men/women respondent due to less concerns on water issues since they are not much influenced.

\section{Descriptive Findings and Discussions}

This section represents the descriptive statistics of the study objective and the dependent variable. To achieve this, a five-point likert scale was used where; 1=Strongly Disagree, 2=Disagree, 3=Undecided.4=Agree, 5=Strongly Agree.

Technological Factors

The study sought to determine the extent to which respondents agreed with the following Statements relating to effect of water technological factors on water accessibility among residents of Baringo North. Results are presented in Table 9. 
INTERNATIONAL JOURNAL OF ACADEMIC RESEARCH IN BUSINESS AND SOCIAL SCIENCES Vol. 10, No. 10, 2020, E-ISSN: 2222-6990 @ 2020 HRMARS

Table 9 Technological Factors

\begin{tabular}{|c|c|c|c|c|c|c|c|c|}
\hline Statements & & SA & A & UD & D & SD & $\begin{array}{l}\text { Mea } \\
\mathrm{n} \\
\end{array}$ & $\begin{array}{l}\text { Std. } \\
\text { Dev. }\end{array}$ \\
\hline \multirow{2}{*}{$\begin{array}{l}\text { 1. The cost of applying } \\
\text { technologies to access } \\
\text { water is low }\end{array}$} & $\mathrm{F}$ & 81 & 143 & 7 & 22 & 22 & 3.86 & 1.160 \\
\hline & $\%$ & 29.5 & 52 & 2.5 & 8 & 8 & & \\
\hline \multirow{2}{*}{$\begin{array}{l}\text { 2. The use of innovations } \\
\text { has enhanced the supply } \\
\text { of water in this region }\end{array}$} & $\mathrm{F}$ & 74 & 148 & 7 & 25 & 21 & 3.82 & 1.064 \\
\hline & $\%$ & 26.9 & 53.8 & 2.5 & 9.1 & 7.6 & & \\
\hline \multirow[b]{2}{*}{$\begin{array}{l}\text { 3. Technological tools and } \\
\text { equipment have help in } \\
\text { accessing water source } \\
\text { and water without } \\
\text { fluoride }\end{array}$} & $\mathrm{F}$ & 54 & 150 & 18 & 26 & 27 & 3.64 & 1.185 \\
\hline & $\%$ & 19.6 & 54.5 & 6.5 & 9.5 & 9.8 & & \\
\hline \multirow{2}{*}{$\begin{array}{l}\text { 4. Since the use of technical } \\
\text { expert, water supply has } \\
\text { been efficient and } \\
\text { sustainable }\end{array}$} & $F$ & 83 & 147 & 4 & 21 & 20 & 3.92 & 1.12 \\
\hline & $\%$ & 30.2 & 53.5 & 1.5 & 7.6 & 7.3 & & \\
\hline Valid $\mathbf{N}=$ & 275 & & & & & & 3.81 & \\
\hline
\end{tabular}

Table 9 shows that $224(81.5 \%)$ of the respondents agreed and $44(16 \%)$ of the respondents disagreed with the statement that the cost of applying technologies to access water is low. Further the study findings showed in terms of means and standard deviation that the cost of applying technologies to access water is low (Mean=3.86, Std. dev=1.160). Also, 222(80.7\%) of the respondents agreed and $46(16.7 \%)$ of the respondents disagreed with the statement that the use of innovations has enhanced the supply of water in this region. Further the study findings showed in terms of means and standard deviation that the use of innovations has enhanced the supply of water in this region (Mean=3.82, Std. dev=1.064).

Further, 194(70.5\%) of the respondents agreed and 53(19.3\%) of the respondents disagreed with the statement that technological tools and equipment has help in accessing water source and water without fluoride. Further the study findings showed in terms of means and standard deviation that Technological tools and equipment has help in accessing water source and water without fluoride (Mean=3.64, Std. dev=1.185). Finally, 230(83.6\%) of the respondents agreed and $41(14.9 \%)$ of the respondents disagreed with the statement that since the use of technical expert, water supply has been efficient and sustainable. Further the study findings showed in terms of means and standard deviation that since the use of technical expert, water supply has been efficient and sustainable (Mean=3.92, Std. dev=1.112). The study results also reveal that water technological factors on water accessibility among residents of Baringo North. This implies that the cost of applying technologies to access water is low. The innovations have enhanced the supply of water in this region, it has help in accessing water source and water without fluoride and water supply has been efficient and sustainable.

The study results concur with Achieno and Mwangangi who investigated on technology use of sustainability of rural community-based water projects in Narok County, Kenya. The results revealed that project management projects have a positive and significant relationship with sustainability 
INTERNATIONAL JOURNAL OF ACADEMIC RESEARCH IN BUSINESS AND SOCIAL SCIENCES Vol. 10, No. 10, 2020, E-ISSN: 2222-6990 @ 2020 HRMARS

among rural community-based water projects with technology use and post implementation support being positive and significant. The study results also concur with Tafara (2013) who carried out a study to establish the water supply system on sustainability of rural community-based water projects in Mtito Andei, Kibwezi sub-county, Kenya. The study established that challenges affecting constant supply of water to the households were due to lack of information management systems, automated systems and appropriate tools and equipment.

\section{Inferential Analysis}

This section consists of correlation and regression analysis. The section was meant to achieve both general and specific objectives in establishing the relationships that exists between the study variables.

\section{Correlation Analysis Results \\ Correlation Analysis}

Correlation analysis was done to achieve the study specific objectives. The findings are presented in Table 10.

Table 10 Correlations Analysis Results

\begin{tabular}{|l|l|}
\hline Variable $(\mathrm{N}=275)$ & Water accessibility \\
\hline Water accessibility & 1 \\
\hline Technological factors & $.413^{* *}$ \\
\hline
\end{tabular}

**. Correlation is significant at the 0.01 level (2-tailed).

The findings revealed that technological factors were strongly positively and statistically significant correlated to water accessibility $(r=0.413 p<0.01)$. This gave an implication that all the study variables were positively correlated to water accessibility. Technological factors contribute $41.3 \%$ to water accessibility.

Table 11 Regression Analysis Coefficient

\begin{tabular}{llllll}
\hline & \multicolumn{2}{l}{$\begin{array}{l}\text { Unstandardized } \\
\text { Coefficients }\end{array}$} & $\begin{array}{l}\text { Standardized } \\
\text { Coefficients }\end{array}$ & T & Sig. \\
\cline { 2 - 5 } & B & Std. Error & Beta & & \\
\hline (Constant) & .869 & .280 & & 3.107 & .002 \\
Technological factors & .284 & .051 & .232 & 5.531 & .000 \\
\hline
\end{tabular}

The optimal model was;

$Y=0.869+0.284 X_{1}$

\section{Hypothesis Testing}

$\mathbf{H}_{01}$ : Technological factors have no significant effect on water accessibility among residents of Baringo North. The regression results in Table 11 indicate that there is significant relationship between technological factors and water accessibility with a beta coefficient of 0.284 and significance of $(p=$ 
INTERNATIONAL JOURNAL OF ACADEMIC RESEARCH IN BUSINESS AND SOCIAL SCIENCES Vol. 10, No. 10, 2020, E-ISSN: 2222-6990 @ 2020 HRMARS

0.000). The study rejected the hypothesis. These results concur with Achieno and Mwangangi who investigated on technology use of sustainability of rural community-based water projects in Narok County, Kenya. The results revealed that project management projects have a positive and significant relationship with sustainability among rural community-based water projects with technology use and post implementation support being positive and significant. The study agreed with Achieno and Mwangangi (2018) whose results revealed that community participation and project management practices have a positive and significant relationship with sustainability among rural communitybased water projects while technology use and post implementation support had a low relationship with sustainability of rural community-based water projects.

\section{Summary, Conclusions and Recommendations Technological Factors}

The respondents agreed in all aspects of technological factors that the cost of applying technologies to access water is low, the use of innovations has enhanced the supply of water in this region, technological tools and equipment has help in accessing water source and water without fluoride and that since the use of technical expert, water supply has been efficient and sustainable.

The study findings also showed that technological factors were statistically significant and have positive influence on water accessibility among residents of Baringo North. The study findings also revealed that water technological factors on water accessibility among residents of Baringo North. This implies that the cost of applying technologies to access water is low. The innovations have enhanced the supply of water in this region, it has help in accessing water source and water without fluoride and water supply has been efficient and sustainable.

\section{Conclusions of the Study}

The study established that technological factors had a direct influence on implementation of water projects in Baringo North sub-County. Therefore, the study concludes that technological factors, in implementation of water projects should be articulated in the implementation plan and that Local beneficiaries must be involved in all stages in the implementation process.

Since the study found out that the technological factors had a direct influence on implementation of water projects in Baringo North sub-County there is need to utilized it well. The county should use technology in water accessibility among residents, since the cost of applying technologies to access water is low and will benefit the community. Technological tools and equipment can be used treat water from fluoride. 
INTERNATIONAL JOURNAL OF ACADEMIC RESEARCH IN BUSINESS AND SOCIAL SCIENCES Vol. 10, No. 10, 2020, E-ISSN: 2222-6990 @ 2020 HRMARS

\section{References}

Achieno, G. O., \& Mwangangi, P. (2018). Determinants of Sustainability of Rural Community Based Water Projects in Narok County, Kenya. International Journal of Entrepreneurship and Project Management, 3(1), 41-57.

Burak, O., \& Yurchenko, D. (2015). Nachhaltige Entwicklung-Besonderheiten Der Umsetzung In Die Praxis OM Beketov National University of Urban Economy in Kharkiv. Information Polity, 19(3, 4), 207-224

Cherlet, J. (2014). Epistemic and Technological Theory in Development Aid. Science, Technology, \& Human Values, 39(6), 773-794.

Connor, R. (2015). The United Nations World Water Development Report 2015: Water for A Sustainable World, Russia; UNESCO Publishing.

Cooper, D. R., \& Schindler, P. S. (2014). Business Research Methods. New York: Mcgraw- Hill Companies.

Drew, R. (2016). Technological Theory. A Companion to Popular Culture. New Jersey: John Wiley \& Sons

Endo, A., Tsurita, I., Burnett, K., \& Orencio, P. M. (2017). A Review of the Current State of Research on the Water, Energy, and Food Nexus. Journal of Hydrology: Regional Studies, 11(2), 20-30.

Flick, U. (2015). Introducing research methodology: A beginner's guide to doing a research project. Newcastle upon Tyne: Sage.

Garrick, D., \& Hall, J. W. (2014). Water Security and Society: Risks, Metrics, And Pathways. Annual Review of Environment and Resources, 39(3), 611-639.

Gazzola, M. (2014). The Evaluation of Language Regimes: Theory and Application to Multilingual Patent Organizations. Amsterdam: John Benjamins Publishing Company.

Githua, R. W., \& Wanyoike, D. M. (2015). Factors Influencing Performance of Community Water Projects in Njoro Sub County. International Journal of Economics, Commerce and Management, 3(11), 967-990.

Gracceva, F., \& Zeniewski, P. (2014). A Systemic Approach to Assessing Energy Security in A LowCarbon EU Energy System. Applied Energy, 123(4), 335-348.

Ivongo, E. M., \& Chege, P. (2019). Information Technology and Performance of County Water Projects: A Case of Makueni County. International Academic Journal of Information Sciences and Project Management, 3(3), 259-288.

Khan, S. N. (2014). Qualitative research method-phenomenology. Asian Social Science, 10(21), 298306.

Kiaritha, H. W. (2015). Determinants of The Financial Performance of Savings and Credit CoOperatives in the Banking Sector in Kenya. Strategic Journal of Business \& Change Management, 3(4), 110-120.

Kimberlin, C. L., \& Winterstein, A. G. (2008). Validity and Reliability of Measurement Instruments Used in Research. American Journal of Health-System Pharmacy, 65(23), 2276-2284.

Ko, C. H. (2017). Accessibility of Radio Frequency Identification Technology in Facilities Maintenance. Journal of Engineering, Project \& Production Management, 7(1), 111-115.

Koskei, E. (2019). Constraints to Use of Rainwater Harvesting Technologies as an Adaptation Strategy to Climate Change in Baringo County. Environmental health insights, 13(6), 11-78. 
INTERNATIONAL JOURNAL OF ACADEMIC RESEARCH IN BUSINESS AND SOCIAL SCIENCES Vol. 10, No. 10, 2020, E-ISSN: 2222-6990 @ 2020 HRMARS

Koskei, E. C., Koskei, R. C., Koske, M. C., \& Koech, H. K. (2013). Effect of Socio-Economic Factors on Access to Improved Water Sources and Basic Sanitation in Bomet Municipality, Kenya. Research Journal of Environmental and Earth Sciences, 5(12), 714-719.

Kothari, C. R. (2004). Research Methodology: Methods and Techniques. New Dheli: New Age International.

Kothari, C. R. (2017). Research Methodology Methods and Techniques Second Edition. New Delhi: New Age International

Lawson, C. (2013). Technology, Technological Theory and the Transformational Model of Social Activity. Abington: Routledge.

Maxwell, J. A. (2012). Qualitative Research Design: An Interactive Approach California: Sage Publications.

Mugenda, O. M., \& Mugenda, A. G. (2003). Research Methods: Quantitative. Nairobi: African Centre For Technology Studies.

Mugo, E. W., \& Nyaegah, J. O. (2018). Role of Information Technology Skills on Youth Empowerment Projects: A Case of Nakuru Town, Kenya. International Academic Journal of Information Sciences and Project Management, 3(2), 345-363.

Muhammad, A. H. (2018). An Assessment of Internet Use for Research in Selected Universities in North-Central Nigeria. The Nigerian Journal of Communication, 15(1) 765-800.

Muriuki, F. W. (2012). Social Factors Influencing the Performance of Water Projects: The Case of Gatamathi Water and Sanitation Company in Murang'a County, Kenya. The International Journal of Business \& Management, 3(1), 77-80.

Ngumi, W. G. (2013). Use of Mobile Applications to Gain Sustainable Competitive Advantage at The Kenya Medical Supplies Authority (Kemsa). Pharm Pharmacol, 8(17), 438-440

Okiro, K., \& Ndungu, J. (2013). The Impact of Mobile and Internet Banking on Performance of Financial Institutions in Kenya. European Scientific Journal, 9(13), 234-240.

Ondiba, H. A., \& Matsui, K. (2019). Social Attributes and Factors Influencing Entrepreneurial Behaviors Among Rural Women in Kakamega County, Kenya. Journal of Global Entrepreneurship Research, 9(1), 2-3.

Papagiannis, F., Gazzola, P., Burak, O., \& Pokutsa, I. (2018). Overhauls in Water Supply Systems in Ukraine: A Hydro-Economic Model of Socially Responsible Planning and Cost Management. Journal of Cleaner Production, 183(2), 358-369.

Pearl, J., \& Mackenzie, D. (2018). The Book of Why: The New Science of Cause and Effect. New York: Basic Books.

Singh, A. S., \& Masuku, M. B. (2013). Fundamental of Applied Research and Sampling Techniques. Int J Med Appl Sci, 2(4), 123-124.

Tafara, A. C. (2013). Factors Influencing Sustainability of Rural Community-Based Water Projects in Mtito Andei, Kibwezi Sub-County, Kenya. Interdiscip. J. Contemp. Res. Bus, 2(3), 74-79.

Tifow, A. (2013). Factors Influencing Sustainability of Rural Water Supplies in Kenya. International Academic Journal of Law and Society, 1(2), 353-373.

WHO/UNICEF Joint Water Supply, \& Sanitation Monitoring Programme. (2014). Progress on Drinking Water and Sanitation: 2014 Update. Geneva: World Health Organization.

Wyatt, M. (2016). Are They Becoming More Reflective And/Or Efficacious? A Conceptual Model Mapping How Teachers' Self-Efficacy Beliefs Might Grow. Educational Review, 68(1), 114137. 
INTERNATIONAL JOURNAL OF ACADEMIC RESEARCH IN BUSINESS AND SOCIAL SCIENCES Vol. 10, No. 10, 2020, E-ISSN: 2222-6990 @ 2020 HRMARS

Wyatt, S. (2008). Technological Theory Is Dead; Long Live Technological Theory. The Handbook of Science and Technology Studies, 3(2), 165-180. 